\title{
Risk preferences in future military leaders
}

\author{
Patrick Bell ${ }^{1}$, Rozlyn Engel ${ }^{2}$, Darren Hudson ${ }^{3 *}$, Julian Jamison ${ }^{4}$, William Skimmyhorn ${ }^{5}$
}

\begin{abstract}
Although hundreds of studies have demonstrated that risk preferences shape people's choices under uncertainty, the complexity of how attitudes toward risk play out across various pivotal settings and key populations leaves considerable gaps in knowledge. We study a unique sample of a cohort of future military leaders at the United States Military Academy (West Point), nearly all of whom now hold commissions in the US Army officer corps. Using a hypothetical instrument to elicit preferences across a variety of domains, we find that cadets are risk averse, on average, which has potentially important implications for future management of military conflicts and programs. Our results also show that diversity programs aimed at increasing the number of women and minorities at West Point are likely to increase the average level of risk aversion within the officer corps. This finding suggests that working with officers to strengthen cognitive flexibility and to be attuned to a possible wedge between their innate preferences and the needs of the situation may be important, particularly for those who wish to enter occupational fields where the willingness to take risks is critical.
\end{abstract}

JEL Classification: C83; C91; D12; D14; D81; G11; I12

\section{Keywords}

risk preferences — risk aversion — uncertainty — occupational risk — leadership

${ }^{1}$ United States Military Academy

${ }^{2}$ Carnegie Endowment for International Peace

${ }^{3}$ Texas Tech University

${ }^{4}$ University of Exeter Business School

${ }^{5}$ College of William and Mary

*Corresponding author: darren.hudson@ttu.edu

\section{Introduction}

Military leaders often make dozens of consequential decisions over the course of a day. Those decisions, whether designing and operating supply routes, maneuvering armor units on a battlefield, or determining the strategy for attacking a fixed position, are made under various states of uncertainty and have high stakes given the inherent risks to human lives and material and to the overall success of the mission. Off the battlefield, military leaders are also called upon to counsel young soldiers on financial management, personal relationships, and health choices, and to make similar choices for their own families. These decisions have important consequences for the well-being of military households and for US national security.

The significance of military decision-making leads us to a unique sample of military personnel to explore the factors shaping this population's choices. We used well-established techniques to design a survey to elicit individual risk preferences across a range of situations. We then administered that survey to a sample of more than 1,000 West Point cadets, nearly all of whom have now assumed military leadership roles. In the final step, we married each cadet's survey results with data from his or her administrative files to analyze the role of personal characteristics in cadet decision-making. We believe that our sample, while very selective compared to the general population, provides important evidence on the risk preferences and decision-making of a significant portion of the Army's officer corps. Hence, a better understanding of this group's risk preferences in a variety of contexts and across several domains will inform future policy formulation, from benefits structure to training doctrine, relating to US military personnel management.

\section{Relevant literature}

The theory of risk preferences as expressed in expected utility theory is well established, and hundreds of studies have been published demonstrating how risk preferences shape people's choices under uncertainty ${ }^{1}$. These studies face several common challenges, however, the first among them being the proper elicitation of risk preferences. At the outset, the elicitation procedure is shaped by the nature of the decision to be studied -in particular, what are the risks associated with the choice being presented (the probabilities) and what are the risk preferences of the decision-maker in question (the degree of convexity of the expected utility function). Researchers then design a range of experiments to illuminate those preferences. Second, the elicitation techniques tend to fall into two broad categories -hypothetical (non-incentivized scenarios)

\footnotetext{
${ }^{1}$ The literature on risk preference elicitation is quite large, but Harrison and Rütstrom (2008a) provide a good overview.
} 
and non-hypothetical (introducing at least some element of 'real world' decision-making) - with a broad literature exploring the differences between the two approaches (Holt and Laury, 2005; Eckel and Grossman, 2008; Cullen et al., 2014; Cubitt et al., 2001). Researchers debate, for example, whether hypothetical elicitation is subject to hypothetical bias (Harrison and Rüstrom, 2008b; Murphy et al., 2005), in which subjects respond according to how they believe (or would like to believe) they would act in real life, rather than expressing their true revealed preferences. At the same time, hypothetical mechanisms allow researchers to address larger samples on a wide range of potential questions simultaneously. For our purposes, we utlilize hypothetical approaches so that we can utilize larger samples in more contexts. Because were are examining consistency more than predictive power, hypothetical bias is less of an issue here.

Once the basic elicitation technique is settled, the next challenge is to ensure the stability of the risk preferences within the given experimental design. A large body of evidence suggests that risk preferences are not stable across contexts or elicitation methods (Reynaud and Couture, 2012; Hudson, Lusk, and Coble, 2005; Anderson and Mellor, 2008; Berg, Dickhaut, and McCabe, 2005; Chuang and Schechter, 2015). Some evidence suggests that context-free lottery choices do have predictive power in risky choices (Lusk and Coble, 2005), and numerous studies find that less formal, hypothetical stated choices are related to risky choices in a theoretically consistent way. Because this lack of preference stability complicates the task of isolating risk preferences in the choice problem, researchers have tended to build sets of closely related questions to test the stability of risk preferences within a given domain (von Gaudecker, van Soest, and Wengström, 2011a). Pennings and Garcia (2001), for example, find evidence that a composite measure of risk preferences across elicitation contexts and methods can have predictive power in risky choice situations. This paper follows a similar approach with clusters of questions focused on a few key domains.

A final challenge is how to balance feasibility and cost against loss of generalizability. For example, eliciting risk preferences from selected (nonrandom) populations, such as students, tends to be highly cost effective but also tends to reduce average risk aversion and the heterogeneity of risk preferences relative to a general population, suggesting that the generalizability of results to broader groups is more limited (von Gaudecker, van Soest, and Wengström, 2011b). Even when the target population is relatively narrow (such as military leaders), it can be logistically and financially difficult to bring them into a laboratory (either physical or virtual) for rigorous and fully incentivized study. To balance these tradeoffs, we opted to use a student sample, but because our student population (West Point cadets) closely resembles and will join our population of interest (Army officers) we believe the loss of generalizability is less of a concern.

In addition to the many considerations affecting the choice of elicitation technique, researchers have also wrestled with how to distinguish the individual's risk perceptions -his or her assessment of the underlying probabilities- from the individual's stated risk preferences as expressed in specific experimental settings. In other words, when researchers observe a subject's choice within a given risky situation, they are seeing the product of two latent explanatory variables, risk perceptions and risk preferences. To estimate the effects of one of these variables, therefore, requires fixing the other one. In the case of military leaders (as in most other populations), we are most interested in estimating their risk preferences, thus we need a way to control for the risk perceptions.

Theoretically, the formation of risk perceptions should be a straightforward objective exercise of assessing the relative probabilities of events occurring. If we know the probabilities, we should just be able to use them as controls. However, this cognitive process depends on the amount of information available to the individual, which is very often limited or quite noisy. Many events, for example, are difficult to predict with any real precision. What is the probability a particular path will contain improvised explosive devices (IEDs)? What are the chances the enemy has established an ambush in front of us? What is the probability that our amphibious assault will be repelled on the beach? This lack of data has a tendency to push even the most ardent empiricists into more subjective (sometimes referred to as "ambiguous") assessments of an event occurring.

Researchers have hypothesized that, in the face of incomplete information, other variables play a role in the formation of risk perceptions. Previous literature suggests that variables as nebulous as personality type and cultural background affect stated risk preferences (Yang, Coble, and Hudson, 2009; Haynes et al., 2008), as does the method by which estimates are generated (Coble, Yang, and Hudson, 2011; Cooke and Goossens, 2004; Lloyd, 2003; Charness, Gneezy, and Imas, 2013). Researchers have also suggested that the presence of conflicting information leads subjects to rely on other frameworks to assign probabilities. It is clear that perceptions of risk are key determinants in risky choices in a variety of contexts (Lusk and Coble, 2005, 2008; Lerner et al., 2003) as well as personal experiences (e.g., experiencing anger or conflict; Kelly et al., 2009) and background risk of other unrelated events (Cullen et al., 2014; Heaton and Lucas, 2000; Eeckhoudt, Gollier, and Schlesinger, 1996; Lusk and Coble, 2008). The heuristics and biases in risk perceptions are interesting and well established (e.g., Kahenman and Tversky 1974), but beyond the scope of this study. We remain interested, however, in combining the perceptions of risk and individual risk preferences to predict consequential choices. More broadly, individual characteristics influence risk preferences. In the current paper, we focus on observable characteristics to explain risk preferences in part because from a policy perspective, we need to identify factors to explain preferences from data that are easily and inexpensively obtained.

In light of the role that more subjective heuristics could be playing, numerous studies have estimated the effects of 
individual characteristics on decision-making under uncertainty, including many involving student populations (Keown, 1989; Cleve et al., 2013). There are, however, surprisingly few direct studies of decision-theoretic preferences in military settings, none of which focus primarily on risk. Lahav et al. (2011) examined time preferences (discount rates) for those in the military compared with other control groups. They found that military members exhibited higher relative discount rates, which they attributed to perceptions of higher occupational risk than that within the general population. Other studies (Warner and Pleeter 2001; Simon, Warner and Pleeter 2015) estimated personal discount rates for military members using variation in retirement plan timing and benefits, finding rates between 0 and $30 \%$ in the earlier study and $2-7 \%$ in the more recent study. While not a direct test of risk preferences, these studies suggest that risk preferences may differ between military and non-military respondents. Other research highlight the role of environmental factors and experience. McKenna et al. (2007) show that sleep deprivation alters risk preferences (in the general population) and Kelly et al. (2009) show that combat deployments tend to increase post-war risk-taking behavior. And, there are data presented on risk-taking behavior of current and past soldiers (Garyn-Tal and Shahrabani, 2015) as well as drug and alcohol abuse among returning combat soldiers (Wilk et al., 2010). Overall, however, we do not know of any research directly estimating the risk preferences of military leaders, a key contribution of this paper. And, which comparisons between non- and military members would be interesting, our focus is on variation in risk preferences among future military leaders.

\section{Data and methods}

We study a unique sample of future military leaders from the United States Military Academy at West Point ${ }^{2}$. West Point is a federally funded four-year undergraduate institution with approximately 4,500 students. All students complete a liberal arts education with a significant core curriculum focused on math, science and engineering, and all graduates earn a Bachelor of Science degree in one of dozens of majors. In addition to its academic requirements, West Point provides leadership development through military, physical and character development programs. To provide some comparison to other undergraduate settings, Integrated Postsecondary Education Data System (IPEDS) data suggest that West Point's near-peer institutions in terms of SAT scores are the University of Wisconsin and Boston University ${ }^{3}$. National ranking systems place West Point between Massachusetts Institute of Technology and the University of Pennsylvania (Forbes) and between Colgate University and Macalester College (U.S.

\footnotetext{
${ }^{2}$ While the majority of these students will receive commissions as officers in the United States Army, some students cross-commission into other military branches while others are cadets from foreign militaries.

${ }^{3}$ We estimate a median SAT score for each institution using IPEDS data for the Class of 2017. We estimate the median using the average of the $25^{\text {th }}$ and $75^{\text {th }}$ percentiles for each institution.
}

News and World Report) ${ }^{4}$.

Because all West Point graduates become U.S. Army officers for a fixed period after graduation (five years on active duty plus another three years either on active duty or in the reserves) and many continue on to longer military careers, these cadets provide a unique opportunity to study risk preferences among future military leaders. Moreover, West Point graduates constitute a large proportion of the Army officer corps, and a disproportionate number serve in combat roles. Therefore, while using student samples can lead to biased results (von Gaudecker, van Soest, and Wengström, 2011b), these students represent a unique opportunity to study individuals who will comprise a large proportion of the population of interest (military decision-makers). This direct match between sample characteristics and the target population of interest justifies our novel sample.

To conduct this research, we had instructors in a semesterlong "Principles of Economics" course at West Point administer a survey during a 60-minute block of a 90-minute lab period during the 2011-2012 academic year ${ }^{5}$. The mandatory nature of the course helps avoid concerns over selection. The course is required for all students at West Point and nearly all students take the course during their sophomore year. Our sample represents $87 \%$ of the cohort that earned a commission from West Point in May $2014^{6}$.

Prior to distributing the survey, instructors advised students that the questionnaire related to making decisions under uncertainty. Students provided consent prior to participation; those who did not consent were assigned a reading and writing exercise. After the consent procedure, students completed a written (fall term) or online (spring term) questionnaire, of which there were four versions with each consisting of 50 questions on the same topics ${ }^{7}$. Instructors distributed the versions randomly with approximately balanced numbers within each section of students (approximately 14-18 students). We achieved a strong completion rate of $85 \%$, unsurprising given that students were encouraged to answer all the questions; hence, the results are strongly representative of the cohort. However, in some cases, items were left blank or answers were infeasible, so our observation counts vary slightly across

\footnotetext{
${ }^{4}$ For the Forbes rankings see: forbes.com/top-colleges/list/. For the U.S. News Rankings see: colleges.usnews.rankingsandreviews.com/bestcolleges/rankings/national-liberal-arts-colleges/data.

5 The full survey instrument can be found in the appendix.

6 There are a handful of students that are not represented in the sample because of scheduling, because they validated out of the course, or because they may have taken the class as a freshman. We have some data on $\mathrm{N}=1,055$ $(89 \%)$ of the class and complete data on $\mathrm{N}=1,028$ (87\%) of the class.

7 The four versions differed deliberately and randomly along a few dimensions. We varied the framing (gain vs. loss) for the disease policy question (6) and military convoy question (18). We varied the presentation of the information (words vs. pictures) for the $\$ 30 \mathrm{~K}$ loan allocation question (17) and the $\$ 500$ retirement savings question (16). We varied the partners (West Point company peer vs. High School peer) for the dictator game question (36) and ultimatum game question (39). We provided peer priming using a question (32) in two versions. Finally, we varied the order (early vs. late) for the logic questions $(13,14,15)$. The questions were otherwise identical and we control for the version in our analyses.
} 


\begin{tabular}{lccccc}
\hline Variable & Obs & Mean & Std. Dev. & Min & Max \\
\hline College Entrance Exam and Class Rank (CEER) & 1028 & 605,73 & 67,96 & 387 & 780 \\
Cumulative Academic Performance Score (CAPS) & 1028 & 3,02 & 0,556 & 1,42 & 4,22 \\
Community Leader Score (CLS) & 1028 & 615,65 & 50,23 & 427 & 745 \\
Recruited Athlete (Recath) & 1028 & 0,183 & 0,387 & 0 & 1 \\
Cumulative Physical Performance Score (CPPS) & 1028 & 2,84 & 0,420 & 1,36 & 3,93 \\
Prior Service & 1028 & 0,042 & 0,200 & 0 & 1 \\
Female & 1028 & 0,174 & 0,379 & 0 & 1 \\
Black & 1028 & 0,086 & 0,280 & 0 & 1 \\
Hispanic & 1028 & 0,078 & 0,268 & 0 & 1 \\
Asian & 1028 & 0,068 & 0,252 & 0 & 1 \\
\hline
\end{tabular}

Note. Department of Defense Data. See text for variable definitions.

Table 1. Sample summary statistics

questions. For each student we also observed the timing of the survey (date and time), the timing of the course (scheduling day and time), and the assigned course instructor.

We combined the survey data with cadet administrative data for each of the respondents ${ }^{8}$. Demographic data included race and gender; age data were also available but lacked sufficient variation to use effectively. Cadets who served in the military prior to entering West Point are recorded (Prior service). The reason for inclusion here is that the cadets will be older, have more military experience, and, therefore, may have different risk profiles than other cadets. Admissions data included measures of the student's academic, physical, and leadership potential ${ }^{9}$. The College Entrance Exam and Class Rank (CEER) score is a West Point metric that combines standardized test scores (SAT or ACT) and high school class rank to evaluate the academic potential of applicants. The Community Leader Score (CLS) combines service and leadership activities to evaluate leadership potential ${ }^{10}$. Cadets directly recruited to West Point to play a sport were also recorded (recath). Finally, student performance data at West Point included first-year cumulative academic performance scores (caps) and physical performance scores (cpps), both of which are scored on a $0-4.33$ scale. Table 1 presents summary statistics for the sample's administrative and demographic data.

To elicit the risk preferences of the students, the questionnaire presented a range of choices in several domains. Table 2 summarizes the key questions and the tabulated risk scores (see the Appendix for the full survey items). Because each

\footnotetext{
${ }^{8}$ The survey data were merged to the administrative data by the Office of Economic and Manpower Analysis (OEMA) at West Point. The data were returned in a deidentified form.

${ }^{9}$ For more information, see: usma.edu/admissions/SitePages/Home.aspx or rand.org/content/dam/rand/pubs/research_reports/RR700/RR723/RAND_R R723.pdf

${ }^{10}$ USMA uses these measures to designate some candidates as scholars (i.e., CEER $\geq 650$ ) and/or leaders (i.e., $C L S \geq 650$ ). We use the raw scores in this analysis as opposed to using dichotomous variable designations.
}

question has different types of answers, it is difficult to compare the raw responses across domains. As a result, we assign each cadet a score $\left(\right.$ Score $\left._{i}\right)$ for each risk measure ranging from -1 for risk averse to +1 for risk seeking, with a score of 0 indicating risk neutrality. The purpose of constructing these indices is to normalize risk measurements across questions and facilitate comparisons across domains. We discuss our method for scoring each item below.

Our initial attempt to identify risk preferences was to ask each cadet for a simple self-assessment, which we believed would provide insight into whether his or her answers aligned with observed risk preferences from the rest of the survey; this general method was validated by Dohman et al. (2011). To quantify this Self-Assessment score, we took cadets' responses to how willing they are to take risks compared to their peers, on a 0-10 scale, and rescaled it between -1 for most risk averse to +1 for most risk-seeking, with each point being associated with an increase of 0.2 on the self-assessment score.

Our next attempt to identify cadet risk preferences centered on games of chance and aimed to assess both their willingness to enter and their willingness to pay in risky lottery scenarios. The Lottery Choice scenario attempts to measure cadets' willingness to take risk in a coin toss game. Cadets who engage in a coin toss with a lower expected value than the guaranteed award are seen as risk seeking; cadets who refuse to do a coin toss with a higher expected value than the guaranteed reward are seen as risk averse; and cadets who choose the coin toss with the expected value equal to the guaranteed reward are seen as neither risk seeking nor risk averse. Our Willingness to Pay Lottery Choice scenario is very similar, with cadets who were willing to pay more than the expected winnings scored as risk seeking, those who would pay less than the expected value scored as risk averse, and those paying exactly the expected value as neither risk-seeking nor risk-averse.

We next widened our purview to an assessment of financial 


\begin{tabular}{|c|c|c|c|c|c|c|}
\hline Risk Measure & Description & Obs & Mean & Std. Dev. & Min & Max \\
\hline Self-Assessment $^{a}$ & $\begin{array}{l}\text { Compared to other cadets, how willing are you to take risks }(0-10 \\
\text { scale). }\end{array}$ & 1009 & $-0,078$ & 0,460 & -1 & 1 \\
\hline Lottery Choice & $\begin{array}{l}\text { Choose between (a) } \$ 150 \text { and (b) } 50 / 50 \text { chance of win } \$ 300 / \text { win } \\
\$ 40 \text {; if answer (a), choose between } \$ 150 \text { and } 50 / 50 \text { chance to win } \\
\$ 300 / \text { win } \$ 100 \text {; if answer (b), choose between } \$ 150 \text { and } 50 / 50 \text { chance } \\
\text { to win } \$ 250 / \text { win } \$ 40 \text {. }\end{array}$ & 1026 & $-0,288$ & 0,669 & -1 & 1 \\
\hline WTP Lottery Choice & $\begin{array}{l}\text { How much would you pay to enter a lottery with a } 50 / 50 \text { chance to } \\
\text { win } \$ 250 / \$ 0 \text {. }\end{array}$ & 1017 & $-0,895$ & 0,371 & -1 & 1 \\
\hline Retirement Savings & $\begin{array}{l}\text { Fraction of } \$ 500 \text { monthly retirement savings allocated to single com- } \\
\text { pany stock, mutual fund, bond, or savings account. }\end{array}$ & 1028 & $-0,025$ & 0,338 & -1 & 1 \\
\hline One-Time Savings & $\begin{array}{l}\text { Fraction of } \$ 30,000 \text { loan allocated to single company stock, mutual } \\
\text { fund, bond, or savings account. }\end{array}$ & 1028 & $-0,171$ & 0,351 & -1 & 1 \\
\hline Financial Behaviors & $\begin{array}{l}\text { How frequently do you: buy and sell stocks / gamble (Never, Rarely, } \\
\text { Sometimes, Frequently). }\end{array}$ & 1021 & $-0,832$ & 0,484 & -1 & 1 \\
\hline Driving Behaviors $^{a}$ & $\begin{array}{l}\text { How frequently do you: drive while tired / not wear seatbelt (Never, } \\
\text { Rarely, Sometimes, Frequently). }\end{array}$ & 1024 & $-0,763$ & 0,519 & -1 & 1 \\
\hline Smoking Behaviors & $\begin{array}{l}\text { How frequently do you: smoke (Never, Rarely, Sometimes, Fre- } \\
\text { quently). }\end{array}$ & 1025 & $-0,719$ & 0,695 & -1 & 1 \\
\hline Leg Injury $^{b}$ & $\begin{array}{l}\text { Given a moderately injured leg would you: take painkillers and use a } \\
\text { brace or have surgery that cures or causes permanent damage. }\end{array}$ & 1027 & $-0,439$ & 0,899 & -1 & 1 \\
\hline Disease Outbreak $^{a b}$ & $\begin{array}{l}\text { Given a disease outbreak would you: save } 200 \text { for sure or save } 600 \\
\text { with } 33 \% \text { probability and none with } 67 \% \text { probability. }\end{array}$ & 1026 & 0,469 & 0,499 & 0 & 1 \\
\hline Military Convoy & $\begin{array}{l}\text { Given a dangerous mission would you choose: } 40 \text { soldiers die for } \\
\text { sure or } 33 \% \text { probability nobody dies and } 67 \% \text { probability } 60 \text { soldiers } \\
\text { die. }\end{array}$ & 1025 & 0,364 & 0,481 & 0 & 1 \\
\hline
\end{tabular}

Note. Department of Defense data. The table reports the summary statistics for the risk measure in each row.See Appendix for survey items and text for details on the scoring for each measure. All measures are scaled such that higher values reflect more willingness to take risk. Survey Item 47 corresponds to Self-Assessment, 3, 3a, and 3b to Lottery Choice, 4 to WTP Lottery Choice, 16a-16d to Retirement Savings, 17a-17d to One-Time Savings, 43d, 43g to Financial Behavior, 43b, 43f to Driving Behavior, 47 to Self-Assessment, 43a to Smoking Behavior, 7 to Leg Injury, 6 to Disease Outbreak, 18 to Military Convoy.

${ }^{a}$ Indicates that the question has been reverse scored for consistency (for Driving Behavior only the seatbelt question was reverse scored).

${ }^{b}$ Indicates that the question was asked using a loss frame for one of the two choices (Disease Outbreak or Military Convoy) and a gain frame for the other (randomized using different versions).

Table 2. Measures of willingness to take risk

risk preferences. Our Monthly Retirement Savings scenario attempts to gauge cadet risk preferences by giving cadets a predetermined amount of money to allocate to retirement savings and observing the proportion that go into risky assets versus safe assets (see Lusardi and Mitchell for similar question constructs). Our scoring identifies single-company stock as most risky, savings accounts as most risk averse, with mutual funds and bonds as respectively between the two extremes. Given the long time horizon to retirement for this student population, we deem mutual funds to be the risk-neutral investment ${ }^{11}$. Our

\footnotetext{
${ }^{11}$ Neither bonds nor mutual funds are "risk neutral" strictly speaking. We
}

One Time Savings scenario is very similar to our Monthly Retirement Savings scenario. However, unlike the retirement scenario, the One Time Savings decision does not specify a time horizon for achieving their goals ${ }^{12}$.

treated mutual funds as the mid-point arbitrarily, but coding it differently has little impact on the results.

12 This is a familiar scenario to cadets, as every year Juniors at the United States Military Academy are offered a pre-commissioning loan known as the "Cow Loan". In recent years the loan has been in excess of $\$ 35,000$ with interest rates of approximately $0.75 \%$ for five years. The lack of a time horizon has some impact on potential estimation of implied discount rates, but does not change the underlying risk of the investment. 
With a similar desire to ascertain behavioral risk aversion, we provided cadets with a Leg Injury scenario in which cadets had to choose between wearing a brace and taking painkillers, or undergoing an operation that could either cure them or permanently damage their knee. Cadets who declined the surgery were deemed risk averse, and those who put their knee at risk of permanent damage deemed risk-seeking.

We also explored behavioral risk aversion when their cadets' decisions directly affected the well-being of others. A Disease Outbreak scenario (see Tversky and Kahneman, 1981) gave the cadets two choices: (1) a $100 \%$ chance (certainty) of saving 200 people, or (2) a 33\% chance of saving 600 people and a $67 \%$ chance of saving none. Similarly, a Military Convoy scenario put cadets in charge of selecting a convoy route where one choice would certainly kill 40 of 60 soldiers, and the other choice offered a $33 \%$ chance of no casualties and a $67 \%$ chance of losing all 60 soldiers. In both scenarios the leaders who took the slightly riskier chance (with 198 expected lives saved for Disease Outbreak and 40.2 expected casualties for Military Convoy) were deemed more risk-seeking, while those who did not were assessed as neither risk seeking nor risk averse.

Finally, in an attempt to go beyond the hypothetical, we asked cadets about the frequency with which they gamble and trade stocks. From their responses, we generated a variable representing the riskiness of their Financial Behavior. We also asked cadets how frequently they drive while tired, do not wear their seatbelts, and smoke cigarettes. Based on those responses, we generated variables for Driving and Smoking Behaviors. For the Financial, Driving, and Smoking Behaviors, we scored cadets who rarely or never engage in such behavior as risk averse, and cadets who sometimes or frequently engage in such behavior as risk seeking ${ }^{13}$. The West Point honor code should reduce intentional dishonesty and reduce the potential impacts of biases introduced by that dishonesty.

Next, using our administrative and demographic data, we evaluate the stability of these risk preference measures in our sample. To investigate possible correlation among answers, we run a Spearman rank-order correlation on the scores for the eleven risk scores. The simple correlations capture the general nature of risk preferences across contexts, although they cannot determine the specific nature of any inconsistencies. Overall, we find evidence of stability among our financial risk measures. Additionally, we find these financial risk measures to have significant correlations to many of our other risk measures.

We also explore whether personal characteristics have predictive power over observed risk preferences, using an Ordinary Least Squares model (Equation 1) that regresses

\footnotetext{
${ }^{13}$ For Financial and Driving Behavior, where two related questions were asked, each question was scored 0 (Never), 1 (Rarely), 2 (Sometimes), or 3 (Frequently). The values of the responses to the related questions was used, with a value $>=4$ deemed risk seeking , $<=2$ risk averse, and values of 3 risk neutral. As Smoking Behavior was based on only one question, there was no possibility cadets were deemed risk neutral.
}

each of the 11 risk scores on student-level characteristics:

$$
\begin{array}{r}
\text { Score }_{i}=\beta_{0}+\beta_{1} \text { CEER } \\
+\beta_{5}+\beta_{2} \text { CAPS }_{i}+\beta_{3} \text { CLS }_{i}+\beta_{4} \text { RecAth }_{i} \\
+\beta_{5} \text { CPS }_{i}+\beta_{6} \text { PriorService }_{i}+\beta_{7} \text { Female }_{i}+\beta_{8} \text { Black }_{i} \\
+\beta_{9} \text { Hispanic }_{i}+\beta_{10} \text { Asian }_{i}+\lambda_{\text {ver }}+\theta_{\text {inst }}+\varepsilon_{i}
\end{array}
$$

Score $_{i}$ is the constructed score for each of our risk items (1 through 11), and the right-hand-side variables were defined above. We introduce fixed effects, $\lambda_{v e r}$ and $\theta_{\text {inst }}$, to control for potential variation across survey versions and instructors.

Because of the potential interaction between domain characteristics and personal characteristics, we do not assign, $a$ priori, any expected sign to the control variables. For example, we might expect recruited athletes to be less likely to engage in some risky behaviors like smoking, but they may be more likely to engage in other risky behaviors like high-speed driving. A possible exception is the relatively well-established empirical finding that females exhibit more relative risk aversion than males (Kruger, 2004; Eckel and Grossman, 2008; Sapienza et al., 2009; Borghans, et al., 2009).

Identification of unbiased causal estimates requires us to satisfy the Gauss-Markov assumptions. Our data are only observational, and so we likely fail to satisfy the zero conditional mean assumption. As a result, even though our vector of control variables is relatively rich, our estimates may be biased and so we report and describe the observed relationships without causal language. In addition, we report the estimates for our control variables as they should generate insights about potential latent impacts of different characteristics on risk perceptions, as noted earlier in the paper.

\section{Results}

The summary statistics in Table 2 suggest that cadets are, on average, risk averse, because the means for the majority of the scores are negative. The positive sign on the last two scores in Table 2 is an artifact of the fact that these two measures used zero as their lower bound, rather than -1 . For both Disease Outbreak and Military Convoy, the means fall below 0.5 , indicating that fewer than half of respondents opted for the risk-seeking option ${ }^{14}$. A finding of overall risk aversion is consistent with other studies (Harrison and Rütstrom, 2008a) and shows that this military population follows the broad tendency of the general population although we make no claim about the relative risk aversion of the military population relative to the non-military population.

\footnotetext{
${ }^{14}$ For these two scenarios, cadets had to select from two risky options Accordingly, we scored their options as risk neutral $(0)$ if the cadet chose the option with the greater expected positive outcome and risk-seeking $(+1)$ if the cadet chose the option with a lower expected positive outcome. We believe selecting the option based on expected value represents a risk neutral decision as opposed to risk averse. However, if coded as -1 or +1 , these measures would also reflect risk aversion (Military Convoy mean $=-0.280$ and Disease Outbreak mean $=-0.578$ ).
} 
Using the responses on each of the eleven risk measures, we then analyze the stability of risk preferences across multiple domains using Spearman rank-order correlations. Table 3 presents the results and shows that 26 of the 55 correlations are significant at the $10 \%$ level or lower, although almost all have small correlation coefficients. The average statistically significant correlation is .0468 , the average correlation is .0226 , and only eight correlations are stronger, in absolute terms, than .10. The three strongest correlations involve Risks 3, 4, and 5, all three of which deal with financial risk, so the strong correlation is not surprising. The number of statistically significant correlations across our domains indicates a surprising degree of stability of aggregate risk preferences in our sample; the small size of these correlations might suggest less economic significance. However, Einav et al. (2012) argue that small correlations between risk preference measures or choices (i.e., 0.16 to 0.26 in their setting) actually reflect large economic relationships. While their observed correlations are larger than ours, they measure choices in fewer and less disparate domains than we do. As a result, our results may still reflect a reasonable degree of domain general risk preferences.

Also notable in Table 3 is the significance of the One Time Savings Decision's correlation with 8 of the other 10 risk measures. This measure of financial risk - a single savings decision with no explicit long-term objective like retirementhas a significant positive correlation with the Self-Assessment, Willingness to Pay Lottery Choice, Retirement Savings Decision, and the three behavioral risk measures, and a significant negative correlation with the Leg Injury and Military Convoy decisions. A riskier decision in the financial domain suggests riskier decisions across several of the other domains, but not the last where it suggests more risk-neutral decisions.

The negative correlation with our military convoy route decision indicates the more willing an individual is to engage in risky behavior oneself, the less willing they are to expose others to risk. Our data are observational, so this estimate may not reflect a causal relationship, but the observed correlation is consistent with the broader economic literature on the differences between personal-maximizing and other-regarding behavior (e.g., Hoffman et al., 1996). This result could have interesting and important implications for military planners in that more common measures of financial risk-taking do not appear to be directly related to military risk-taking. So, standard lottery choices may not be an effective predictor of military decisions. Self-assessed risk preference, however, shows some degree of correlation. These issues needs to be carefully investigated as it might fundamentally change the way we assess risk preference of military leaders.

For a more refined examination, we used a paired t-test to examine the within-subject pairwise stability of preferences (Table 4). As can be seen, in virtually all cases measures in different domains are statistically different, suggesting little evidence of stability. And, interestingly, in almost all cases, self-reported risk preferences are less risk averse than those found in specific domains. Taken together, the data indicate that there is some degree of correlation in risk preferences across domains in the aggregate, but within-subject comparisons shows that, on average, there is a great deal of heterogeneity in preferences across those domains.

While the summary statistics and correlations provide useful insights into how risk preferences may vary across broadly defined groups, they do not help us understand what drives the differences among members of the same group. To examine individual-level variations, we regress risk responses for each question against key personal characteristics, such as academic aptitude, athletic ability, gender, and ethnicity, using Equation 1. Table 5 presents the baseline regression results.

Consistent with the descriptive statistics from the overall sample, risk aversion dominates the individual-level regression results. Overall, only two positive coefficients were statistically significant in the eleven regressions (indicating those factors are associated with more risk-taking), compared to fourteen negative coefficients (indicating those factors are associated with more risk-aversion) that were statistically significant. The remainder of this section describes the results in greater detail.

Academic readiness (CEER) is only statistically (and inversely) related to Financial Behavior. In that case, holding all else equal, a one standard deviation increase in CEER score (67.96 point) is associated with a $5.03 \%$ decrease in the risk score (more risk averse). Somewhat intuitively, this result indicates that more academically prepared students tend to be more risk averse, on average, than less well prepared students. It is critical to note, however, that while the result is statistically significant, it is questionable whether it is economically significant: a one standard deviation in CEER score (roughly a $10 \%$ change) results in a small increase in measured risk aversion.

Academic performance (CAPS) only correlates significantly (and negatively) with the Military Convoy decision. In that case, holding all else equal, a one standard deviation increase in CAPS score (0.556 point) is associated with a $9.72 \%$ decrease in the risk score (more risk averse). Again, this result indicates that more academically proficient students tend to be more risk averse when it comes to taking risk in this military decision-making arena than less academically proficient students. Leadership potential (CLS), by contrast, is not statistically significant with any of the risk measures. The CLS measures, in part, leadership positions held prior to college, often captains of high school sports teams ${ }^{15}$. Some of the expected variation with this measure may have been captured by recruited athletes and prior service military measures.

Recruited athlete (RecAth) correlates significantly (and negatively) only with the option on Leg Surgery. Holding all else equal, being a recruited athlete is associated with a 0.152 decrease in the score for deciding to take the riskier option in the Leg Surgery scenario.

\footnotetext{
15 In the most recent West Point admissions profile, 771 of 1257 admitted cadets were team captains in high school.
} 


\begin{tabular}{|c|c|c|c|c|c|c|c|c|c|c|}
\hline & $\begin{array}{c}\text { Self } \\
\text { Assessment }\end{array}$ & $\begin{array}{l}\text { Lottery } \\
\text { Choice }\end{array}$ & $\begin{array}{c}\text { WTP Lottery } \\
\text { Choice }\end{array}$ & $\begin{array}{c}\text { Retirement } \\
\text { Savings }\end{array}$ & $\begin{array}{l}\text { One-Time } \\
\text { Savings }\end{array}$ & $\begin{array}{l}\text { Financial } \\
\text { Behavior }\end{array}$ & $\begin{array}{c}\text { Driving } \\
\text { Behavior }\end{array}$ & $\begin{array}{l}\text { Smoking } \\
\text { Behavior }\end{array}$ & $\begin{array}{c}\text { Leg } \\
\text { Injury }\end{array}$ & $\begin{array}{c}\text { Disease } \\
\text { Outbreak }\end{array}$ \\
\hline $\begin{array}{l}\text { Lottery } \\
\text { Choice }\end{array}$ & $-0,0493$ & & & & & & & & & \\
\hline $\begin{array}{l}\text { WTP Lottery } \\
\text { Choice }\end{array}$ & 0,028 & $0,0534 *$ & & & & & & & & \\
\hline $\begin{array}{l}\text { Retirement } \\
\text { Savings }\end{array}$ & $-0,0953^{*}$ & 0,02 & 0,0185 & & & & & & & \\
\hline $\begin{array}{l}\text { One-Time } \\
\text { Savings }\end{array}$ & $-0,0948 *$ & 0,015 & $0,0612^{*}$ & $0,6576^{*}$ & & & & & & \\
\hline $\begin{array}{l}\text { Financial } \\
\text { Behavior }\end{array}$ & $-0,0932 *$ & 0,011 & $0,0748^{*}$ & $0,1670^{*}$ & $0,2118^{*}$ & & & & & \\
\hline $\begin{array}{l}\text { Driving } \\
\text { Behavior }\end{array}$ & $-0,1131 *$ & 0,035 & $0,0671^{*}$ & $0,0645^{*}$ & $0,1034 *$ & $0,1190^{*}$ & & & & \\
\hline $\begin{array}{l}\text { Smoking } \\
\text { Behavior }\end{array}$ & $-0,0985^{*}$ & $-0,04$ & 0,0018 & $0,0586^{*}$ & $0,0572 *$ & $0,0836^{*}$ & $0,1294 *$ & & & \\
\hline $\begin{array}{l}\text { Leg } \\
\text { Injury }\end{array}$ & 0,0491 & $-0,04$ & $-0,0318$ & $-0,0908^{*}$ & $-0,0694 *$ & 0,0011 & 0,0375 & $0,0540^{*}$ & & \\
\hline $\begin{array}{l}\text { Disease } \\
\text { Outbreak }\end{array}$ & $-0,0032$ & $-0,04$ & $0,0635^{*}$ & $-0,0038$ & $-0,007$ & 0,0173 & $-0,022$ & 0,0427 & 0,03 & \\
\hline $\begin{array}{l}\text { Military } \\
\text { Convoy }\end{array}$ & $0,0655^{*}$ & 0,004 & $-0,0411$ & 0,0032 & $-0,0586^{*}$ & 0,0141 & $-0,024$ & 0,0047 & -0 & $-0,1620^{*}$ \\
\hline
\end{tabular}

Note. Department of Defense Data. For a description of Risk Measures, see Table 2. * reflects $\mathrm{p} \leq 0,10$

Table 3. Risk preference correlation estimates

Physical performance (CPPS) correlates negatively with two of the risk domains. Holding all else equal, individuals whose first-year Physical GPA score is one standard deviation (0.420) higher, on average, than other cadets are $7.64 \%$ less likely to engage in the risky Smoking Behavior option and $5.42 \%$ less likely to opt for the riskier Disease Outbreak option. The relationship between physical performance and not smoking follows intuition. However, there is no plausible intuition to tie this score to the Disease Outbreak decision and may simply be spurious correlation.

Prior military service is not significanty related to any of the risk measures. While prior military service might be expected to have an impact on risk preferences, especially in the military contexts, we find no evidence of differences in preferences between cadets with and without prior military service.

Being female (Female) significantly correlates with four measures inversely and two measures directly. Compared to male cadets and holding all else equal, female cadets score .100 points lower on the Retirement Savings decision, 0.139 points lower on the One Time Savings decision, .112 points lower on Financial Risky Behavior, and 0.164 points lower on Smoking Behavior. Conversely, females scored 0.141 points higher on the Leg Injury decision (opting for surgery more often) and 0.075 points higher than males on the SelfAssessment.

Being African American (Black) significantly correlates with only one of the measures. Comparing to non-black cadets and holding all else equal, a black cadet scores .141 points lower on the Risky Driving Behavior decision. Likewise, being Hispanic (Hispanic) significantly correlates negatively with only one of the specifications. Comparing to non-Hispanic cadets and holding all else equal, a Hispanic cadet scores .105 points lower on the Military Convoy decision. Finally, being Asian (Asian) significantly correlates negatively with three of these measures. Compared to nonAsian cadets and holding all else equal, an Asian cadet scores .104 points lower on the Retirement Savings decision, .092 points lower on the One Time Savings decision, and .123 points lower on the Military Convoy decision.

With a vast majority of variables lacking significance, Table 5 illustrates how difficult it can be to predict decisions under uncertainty with observable variables. Some of the regression results reveal intuitive relationships, such as strong 


\begin{tabular}{|c|c|c|c|c|c|c|c|c|c|c|}
\hline & $\begin{array}{c}\text { Self } \\
\text { Assessment }\end{array}$ & $\begin{array}{l}\text { Lottery } \\
\text { Choice }\end{array}$ & $\begin{array}{c}\text { WTP Lottery } \\
\text { Choice }\end{array}$ & $\begin{array}{c}\text { Retirement } \\
\text { Savings }\end{array}$ & $\begin{array}{l}\text { One-Time } \\
\text { Savings }\end{array}$ & $\begin{array}{l}\text { Financial } \\
\text { Behavior }\end{array}$ & $\begin{array}{c}\text { Driving } \\
\text { Behavior }\end{array}$ & $\begin{array}{l}\text { Smoking } \\
\text { Behavior }\end{array}$ & $\begin{array}{c}\text { Leg } \\
\text { Injury }\end{array}$ & $\begin{array}{c}\text { Disease } \\
\text { Outbreak }\end{array}$ \\
\hline $\begin{array}{l}\text { Lottery } \\
\text { Choice }\end{array}$ & $0,201 * * *$ & & & & & & & & & \\
\hline $\begin{array}{l}\text { WTP Lottery } \\
\text { Choice }\end{array}$ & $0,892 * * *$ & $0,605^{* * *}$ & & & & & & & & \\
\hline $\begin{array}{l}\text { Retirement } \\
\text { Savings }\end{array}$ & $-0,055^{* * *}$ & $-0,263 * * *$ & $-0,869 * * *$ & & & & & & & \\
\hline $\begin{array}{l}\text { One-Time } \\
\text { Savings }\end{array}$ & $0,091 * * *$ & $-0,116 * * *$ & $-0,722 * * *$ & $0,147 * * *$ & & & & & & \\
\hline $\begin{array}{l}\text { Financial } \\
\text { Behavior }\end{array}$ & $0,753 * * *$ & $0,540 * * *$ & $-0,065^{* * *}$ & $0,806 * * *$ & $0,658 * * *$ & & & & & \\
\hline $\begin{array}{l}\text { Driving } \\
\text { Behavior }\end{array}$ & $0,688 * * *$ & $0,473 * * *$ & $-0,132 * * *$ & $0,738 * * *$ & $0,590^{* * * *}$ & $-0,067 * * *$ & & & & \\
\hline $\begin{array}{l}\text { Smoking } \\
\text { Behavior }\end{array}$ & $0,638 * * *$ & $0,434 * * *$ & $-0,170 * * *$ & $0,695^{* * *}$ & $0,548 * * *$ & $0,025^{* * *}$ & $-0,042 *$ & & & \\
\hline $\begin{array}{l}\text { Leg } \\
\text { Injury }\end{array}$ & $0,367 * * *$ & $0,161 * * *$ & $-0,447 * * *$ & $0,424 * * *$ & $0,276^{* * *}$ & $-0,377 * * *$ & $-0,312 * * *$ & $-0,279 * * *$ & & \\
\hline $\begin{array}{l}\text { Disease } \\
\text { Outbreak }\end{array}$ & $-0,553 * * *$ & $-0,759 * * *$ & $-1,36^{* * *}$ & $-0,495^{* * *}$ & $-0,642 * * *$ & $-1,30^{* * *}$ & $-1,23 * * *$ & $-1,19 * * *$ & $-0,918 * * *$ & \\
\hline $\begin{array}{l}\text { Military } \\
\text { Convoy }\end{array}$ & $-0,442 * * *$ & $-0,647 * * *$ & $-1,25 * * *$ & $-0,384 * * *$ & $-0,531 * * *$ & $-1,19 * * *$ & $-1,12 * * *$ & $-1,08 * * *$ & $-0,807 * * *$ & $0,110 * * *$ \\
\hline
\end{tabular}

Note. Department of Defense Data. For a description of Risk Measures, see Table 2. * reflects $p \leq 0,10$

Table 4. Paired t-test mean differences

physical fitness being associated with a lower likelihood of frequent smoking and recruited athletes being associated with a lower likelihood of electing risky surgery. However, two variables in Table 5 show surprising predictive power -being female and being Asian. We therefore analyze these two variables in more depth to explore the extent of the variation and possible interpretations.

Based on the regression results, being female is the single most effective predictor of risk preferences among cadets. Female $(\mathrm{N}=179)$ was significant in describing six risk factors -three financial risk measures (Retirement Savings, One-Time Savings, and Risky Financial Behavior), Smoking Behavior, Self-Assessment, and the Leg Injury decision. For the first four, female cadets scored approximately $10.0 \%, 13.9 \%$, $11.2 \%$, and $16.4 \%$ higher on the risk-avoiding spectrum than males. In the last two, however, female cadets scored $14.1 \%$ and $7.45 \%$ higher on the risk-seeking spectrum than males. There are a few potential explanations for this gender-based difference in risk preferences.

In terms of the Leg Injury decision, it is difficult to find a straightforward interpretation for why women elect risky surgery more frequently. One reason may be that women are more likely to trust doctors than men (Bonds et al., 2004).
But other studies show that men are more likely to opt for some forms of surgery than women (Karlson et al., 1997). A plausible, albeit undocumented, hypothesis is that the decision to attend West Point is inherently riskier for females. Because female cadets compose a smaller portion of the student body than their male counterparts, they may have a higher probability of being selected for hazardous duty than their male peers. Thus, their self-selection into West Point may help explain their higher self-assessment for risk-taking and higher risk tolerance for domains like surgery than the male cadets. However, their higher self-ratings do not appear to carry into financial decision-making, and so their self-reported risk tolerances may be an anomaly or they may see financial risk as quite different from physical risk. Despite the results of higher risk seeking on the last two variables, however, the general finding that females are more risk averse is consistent with findings from evolutionary biology (Kruger, 2004) and experimental economics (Eckel and Grossman, 2008), and applied risk analysis (Halek and Eisenhauer, 2001).

Given the importance of the female and Asian variables, we revisit the descriptive statistics from Table 1 and analyze them by gender and race in Table 6. Taking a look at the gender question first, Panel A presents the risk measures by 


\begin{tabular}{|c|c|c|c|c|c|c|c|c|c|c|c|}
\hline & (1) & (2) & (3) & (4) & (5) & (6) & (7) & (8) & (9) & (10) & (11) \\
\hline Variables & $\begin{array}{c}\text { Self } \\
\text { Assessment }\end{array}$ & $\begin{array}{l}\text { Lottery } \\
\text { Choice }\end{array}$ & $\begin{array}{c}\text { WTP } \\
\text { Lottery } \\
\text { Choice }\end{array}$ & $\begin{array}{l}\text { Retirement } \\
\text { Savings }\end{array}$ & $\begin{array}{c}\text { One Time } \\
\text { Savings }\end{array}$ & $\begin{array}{l}\text { Financial } \\
\text { Behavior }\end{array}$ & $\begin{array}{c}\text { Driving } \\
\text { Behavior }\end{array}$ & $\begin{array}{l}\text { Smoking } \\
\text { Behavior }\end{array}$ & $\begin{array}{c}\text { Leg } \\
\text { Injury }\end{array}$ & $\begin{array}{c}\text { Disease } \\
\text { Outbreak }\end{array}$ & $\begin{array}{l}\text { Military } \\
\text { Convoy }\end{array}$ \\
\hline CEER & $\begin{array}{c}0.000235 \\
(0.000321)\end{array}$ & $\begin{array}{c}4.87 \mathrm{e}-05 \\
(0.000454)\end{array}$ & $\begin{array}{c}0.000412 \\
(0.000259)\end{array}$ & $\begin{array}{c}-1.29 \mathrm{e}-05 \\
(0.000219)\end{array}$ & $\begin{array}{c}1.41 \mathrm{e}-05 \\
(0.000226)\end{array}$ & $\begin{array}{l}-0.000616^{*} \\
(0.000354)\end{array}$ & $\begin{array}{l}-0.000191 \\
(0.000373)\end{array}$ & $\begin{array}{c}0.000398 \\
(0.000468)\end{array}$ & $\begin{array}{c}0.000132 \\
(0.000613)\end{array}$ & $\begin{array}{c}-4.57 \mathrm{e}-05 \\
(0.000309)\end{array}$ & $\begin{array}{r}0.000269 \\
(0.000291)\end{array}$ \\
\hline CAPS & $\begin{array}{c}0.0198 \\
(0.0403) \\
\end{array}$ & $\begin{array}{l}-0.0310 \\
(0.0546) \\
\end{array}$ & $\begin{array}{l}-0.0311 \\
(0.0377) \\
\end{array}$ & $\begin{array}{c}0.0136 \\
(0.0306) \\
\end{array}$ & $\begin{array}{c}-0.00734 \\
(0.0304) \\
\end{array}$ & $\begin{array}{l}-0.0141 \\
(0.0472) \\
\end{array}$ & $\begin{array}{l}-0.0552 \\
(0.0430) \\
\end{array}$ & $\begin{array}{l}-0.0714 \\
(0.0577) \\
\end{array}$ & $\begin{array}{c}-0.125 \\
(0.0763) \\
\end{array}$ & $\begin{array}{c}0.0206 \\
(0.0391) \\
\end{array}$ & $\begin{array}{c}-0.0636^{*} \\
(0.0365) \\
\end{array}$ \\
\hline CLS & $\begin{array}{c}4.77 \mathrm{e}-05 \\
(0.000300)\end{array}$ & $\begin{array}{l}-0.000216 \\
(0.000432)\end{array}$ & $\begin{array}{c}0.000130 \\
(0.000230)\end{array}$ & $\begin{array}{c}0.000312 \\
(0.000216)\end{array}$ & $\begin{array}{c}0.000151 \\
(0.000230)\end{array}$ & $\begin{array}{c}6.08 \mathrm{e}-05 \\
(0.000281)\end{array}$ & $\begin{array}{l}-0.000352 \\
(0.000321)\end{array}$ & $\begin{array}{c}0.000104 \\
(0.000466)\end{array}$ & $\begin{array}{l}-0.000948 \\
(0.000601)\end{array}$ & $\begin{array}{c}0.000301 \\
(0.000296)\end{array}$ & $\begin{array}{r}-8.18 \mathrm{e}-05 \\
(0.000265)\end{array}$ \\
\hline RecAth & $\begin{array}{l}-0.0108 \\
(0.0446)\end{array}$ & $\begin{array}{c}0.0998 \\
(0.0616)\end{array}$ & $\begin{array}{c}0.0369 \\
(0.0327)\end{array}$ & $\begin{array}{l}-0.0341 \\
(0.0306)\end{array}$ & $\begin{array}{l}-0.0159 \\
(0.0339)\end{array}$ & $\begin{array}{l}-0.00985 \\
(0.0490)\end{array}$ & $\begin{array}{l}0.00400 \\
(0.0496)\end{array}$ & $\begin{array}{l}-0.0785 \\
(0.0592)\end{array}$ & $\begin{array}{l}-0.172 * * \\
(0.0768)\end{array}$ & $\begin{array}{l}-0.0265 \\
(0.0411)\end{array}$ & $\begin{array}{l}-0.0112 \\
(0.0379)\end{array}$ \\
\hline CPPS & $\begin{array}{l}-0.0228 \\
(0.0406) \\
\end{array}$ & $\begin{array}{l}-0.0342 \\
(0.0566) \\
\end{array}$ & $\begin{array}{l}-0.0332 \\
(0.0307) \\
\end{array}$ & $\begin{array}{c}0.0325 \\
(0.0315) \\
\end{array}$ & $\begin{array}{c}0.0196 \\
(0.0308) \\
\end{array}$ & $\begin{array}{c}0.0636 \\
(0.0390) \\
\end{array}$ & $\begin{array}{c}0.0528 \\
(0.0443) \\
\end{array}$ & $\begin{array}{l}-0.131^{* *} \\
(0.0608) \\
\end{array}$ & $\begin{array}{l}0.00441 \\
(0.0778) \\
\end{array}$ & $\begin{array}{l}-0.0657^{*} \\
(0.0380) \\
\end{array}$ & $\begin{array}{l}-0.0293 \\
(0.0348) \\
\end{array}$ \\
\hline Prior Service & $\begin{array}{l}-0.0217 \\
(0.0759)\end{array}$ & $\begin{array}{l}-0.0600 \\
(0.0965)\end{array}$ & $\begin{array}{l}0.00813 \\
(0.0581)\end{array}$ & $\begin{array}{c}0.0369 \\
(0.0563)\end{array}$ & $\begin{array}{c}0.0295 \\
(0.0560)\end{array}$ & $\begin{array}{l}-0.00725 \\
(0.0883)\end{array}$ & $\begin{array}{c}0.0464 \\
(0.0712)\end{array}$ & $\begin{array}{c}-0.141 \\
(0.0949)\end{array}$ & $\begin{array}{l}0.0698 \\
(0.155)\end{array}$ & $\begin{array}{c}0.0988 \\
(0.0815)\end{array}$ & $\begin{array}{l}-0.0803 \\
(0.0707)\end{array}$ \\
\hline Female & $\begin{array}{c}0.0745 * * \\
(0.0351) \\
\end{array}$ & $\begin{array}{c}0.0286 \\
(0.0549) \\
\end{array}$ & $\begin{array}{l}-0.0167 \\
(0.0302) \\
\end{array}$ & $\begin{array}{c}-0.0997 * * * \\
(0.0281) \\
\end{array}$ & $\begin{array}{c}-0.139 * * * \\
(0.0288) \\
\end{array}$ & $\begin{array}{c}-0.112 * * * \\
(0.0301) \\
\end{array}$ & $\begin{array}{l}-0.0395 \\
(0.0412) \\
\end{array}$ & $\begin{array}{c}-0.164 * * * \\
(0.0475)\end{array}$ & $\begin{array}{c}0.141 * \\
(0.0779) \\
\end{array}$ & $\begin{array}{c}0.0184 \\
(0.0383) \\
\end{array}$ & $\begin{array}{l}0.00245 \\
(0.0343) \\
\end{array}$ \\
\hline Black & $\begin{array}{l}-0.0134 \\
(0.0593) \\
\end{array}$ & $\begin{array}{c}0.0840 \\
(0.0846) \\
\end{array}$ & $\begin{array}{l}-0.0320 \\
(0.0337) \\
\end{array}$ & $\begin{array}{l}-0.0329 \\
(0.0417) \\
\end{array}$ & $\begin{array}{l}-0.0458 \\
(0.0433) \\
\end{array}$ & $\begin{array}{l}-0.0372 \\
(0.0658) \\
\end{array}$ & $\begin{array}{l}-0.141 * * \\
(0.0565) \\
\end{array}$ & $\begin{array}{l}-0.0197 \\
(0.0834) \\
\end{array}$ & $\begin{array}{c}-0.0442 \\
(0.110) \\
\end{array}$ & $\begin{array}{c}0.0563 \\
(0.0574) \\
\end{array}$ & $\begin{array}{l}-0.0193 \\
(0.0509) \\
\end{array}$ \\
\hline Hispanic & $\begin{array}{l}-0.0292 \\
(0.0619) \\
\end{array}$ & $\begin{array}{l}-0.0341 \\
(0.0796) \\
\end{array}$ & $\begin{array}{c}0.0829 \\
(0.0563) \\
\end{array}$ & $\begin{array}{l}-0.0646 \\
(0.0411) \\
\end{array}$ & $\begin{array}{l}-0.0365 \\
(0.0460) \\
\end{array}$ & $\begin{array}{l}-0.0280 \\
(0.0540) \\
\end{array}$ & $\begin{array}{l}-0.0938 \\
(0.0615) \\
\end{array}$ & $\begin{array}{c}0.0211 \\
(0.0892) \\
\end{array}$ & $\begin{array}{l}0.0242 \\
(0.110) \\
\end{array}$ & $\begin{array}{l}0.00231 \\
(0.0566) \\
\end{array}$ & $\begin{array}{l}-0.105^{* *} \\
(0.0501) \\
\end{array}$ \\
\hline Asian & $\begin{array}{c}0.0424 \\
(0.0550)\end{array}$ & $\begin{array}{l}0.00495 \\
(0.0829)\end{array}$ & $\begin{array}{c}0.0441 \\
(0.0576)\end{array}$ & $\begin{array}{l}-0.104 * * \\
(0.0436)\end{array}$ & $\begin{array}{c}-0.0921^{* *} \\
(0.0410)\end{array}$ & $\begin{array}{l}-0.0753 \\
(0.0509)\end{array}$ & $\begin{array}{l}-0.0232 \\
(0.0692)\end{array}$ & $\begin{array}{l}-0.0448 \\
(0.0794)\end{array}$ & $\begin{array}{l}0.0279 \\
(0.117)\end{array}$ & $\begin{array}{c}0.0154 \\
(0.0543)\end{array}$ & $\begin{array}{l}-0.123 * * \\
(0.0488)\end{array}$ \\
\hline Mean & $-0,078$ & $-0,288$ & $-0,895$ & $-0,025$ & $-0,171$ & $-0,832$ & $-0,763$ & $-0,719$ & $-0,439$ & 0,469 & 0,364 \\
\hline Observations & 1,009 & 1,026 & 1,017 & 1,028 & 1,028 & 1,021 & 1,024 & 1,025 & 1,027 & 1,026 & 1,025 \\
\hline R-squared & 0.024 & 0.026 & 0.042 & 0.047 & 0.059 & 0.034 & 0.026 & 0.040 & 0.034 & 0.209 & 0.304 \\
\hline
\end{tabular}

Note. Department of Defense Data. The table reports OLS estimates of equation 1 for the outcome listed in each column. See text for variable definitions. Heteroskedasticity robust standard errors are listed in parentheses. *, **, and *** reflect $\mathrm{p} \leq 0.10, p \leq 0.05$ and $\mathrm{p} \leq 0.01$.

Table 5. OLS regressions of the correlates of risk preference measures

gender. The results reveal that, on average, females are more risk averse in 7 of the 11 risk measures, with exceptions being Self-Assessment, Lottery Choice, Leg Injury decision, and Military Convoy decision. While some of the differences are numerically large, they are not universal. Consider, for example, the One-Time Savings Decision. Here, females are roughly twice as risk averse as males, a result that Figure 1 displays visually. Figure 1 shows that the distribution of male responses is more right skewed (risk seeking) than female responses, resulting in a higher average value for males.

The implications of this result for one's portfolio choices are clear ${ }^{16}$; what is less clear is whether these observed differences translate into differences relevant for future leadership within the military. For example, because officers are often called upon to counsel soldiers on financial matters, significant gender-based differences in risk preferences may lead to different financial advice from female leaders. While we certainly make no determination of what is "correct" advice, these results do indicate the need for at least some training on (1) risks and returns of various investment alternatives and (2) possible variations in the risk preferences of subordinates

\footnotetext{
16 There is no "right" portfolio allocation. We refer here to choices made facing a portfolio with known risk/return profiles.
}

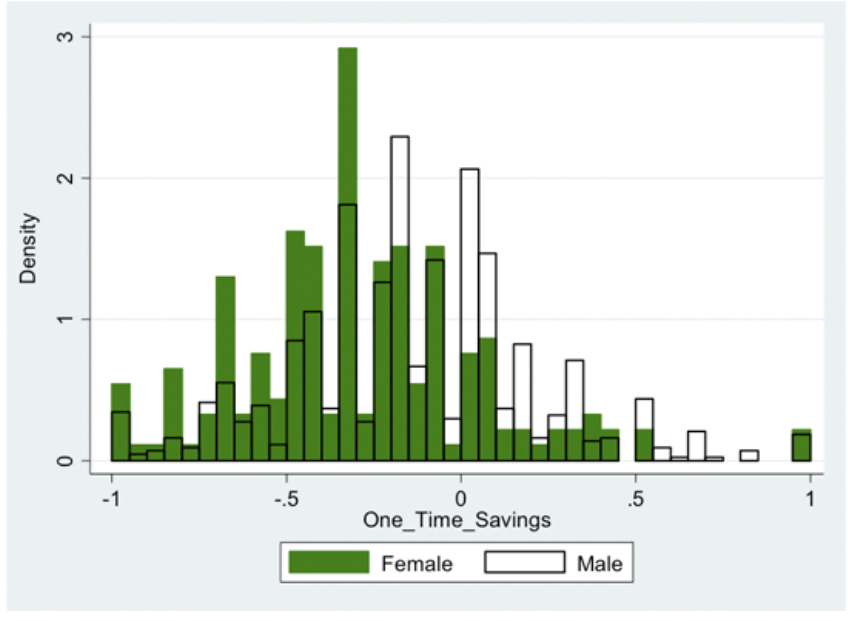

Figure 1

so that advice can be sensitive to risk tolerances. Overall, the higher risk aversion expressed by females suggests that decision-making in the field could differ as well. Data on actual field choices would help to test the validity of this finding.

In Table 6, Panel B presents the risk measures by Asian 


\begin{tabular}{|c|c|c|c|c|c|c|}
\hline & \multicolumn{3}{|c|}{ Panel A: Gender } & \multicolumn{3}{|c|}{ Panel B: Race/Ethnicity } \\
\hline & Male & Female & & Non-Asian & Asian & \\
\hline & $\mathrm{N}$ & $\mathrm{N}$ & Diff & $\mathrm{N}$ & $\mathrm{N}$ & Diff \\
\hline & Mean & Mean & t-stat & Mean & Mean & t-stat \\
\hline \multirow[t]{2}{*}{ Variable } & (SD) & (SD) & $\mathrm{p}$-value & (SD) & (SD) & $\mathrm{p}$-value \\
\hline & 832 & 177 & $-0,08$ & 941 & 68 & $-0,06$ \\
\hline \multirow[t]{3}{*}{ Self-Assessment } & $-0,09$ & $-0,02$ & -1.98 & $-0,08$ & $-0,03$ & $-0,96$ \\
\hline & $(0,47)$ & $(0,40)$ & 0,048 & $(0,46)$ & $(0,42)$ & 0,340 \\
\hline & 848 & 178 & $-0,06$ & 957 & 69 & 0,00 \\
\hline \multirow[t]{3}{*}{ Lottery Choice } & $-0,30$ & $-0,24$ & $-1,03$ & $-0,29$ & $-0,29$ & 0,02 \\
\hline & $(0,67)$ & $(0,65)$ & 0,303 & $(0,67)$ & $(0,64)$ & 0,986 \\
\hline & 841 & 176 & 0,02 & 948 & 69 & $-0,06$ \\
\hline \multirow[t]{3}{*}{ WTP Lottery Choice } & $-0,89$ & $-0,91$ & 0,56 & $-0,90$ & $-0,84$ & $-1,26$ \\
\hline & $(0,37)$ & $(0,36)$ & 0,574 & $(0,36)$ & $(0,47)$ & 0,209 \\
\hline & 849 & 179 & 0,11 & 958 & 70 & 0,09 \\
\hline \multirow[t]{3}{*}{ Retirement Savings } & $-0,01$ & $-0,12$ & 3,97 & $-0,02$ & $-0,11$ & 2,22 \\
\hline & $(0,33)$ & $(0,34)$ & 0,000 & $(0,34)$ & $(0,36)$ & 0,027 \\
\hline & 849 & 179 & 0,15 & 958 & 70 & 0,08 \\
\hline \multirow[t]{3}{*}{ One-Time Savings } & $-0,15$ & $-0,29$ & 5,10 & $-0,16$ & $-0,25$ & 1,93 \\
\hline & $(0,35)$ & $(0,35)$ & 0,000 & $(0,35)$ & $(0,35)$ & 0,054 \\
\hline & 845 & 176 & 0,12 & 951 & 70 & 0,07 \\
\hline \multirow[t]{3}{*}{ Financial Behavior } & $-0,81$ & $-0,93$ & 3,03 & $-0,83$ & $-0,90$ & 1,23 \\
\hline & $(0,51)$ & $(0,31)$ & 0,002 & $(0,49)$ & $(0,39)$ & 0,220 \\
\hline & 848 & 176 & 0,03 & 954 & 70 & 0,01 \\
\hline \multirow[t]{3}{*}{ Driving Behavior } & $-0,76$ & $-0,79$ & 0,76 & $-0,76$ & $-0,77$ & 0,15 \\
\hline & $(0,52)$ & $(0,50)$ & 0,447 & $(0,52)$ & $(0,54)$ & 0,884 \\
\hline & 848 & 177 & 0,16 & 955 & 70 & 0,06 \\
\hline \multirow[t]{3}{*}{ Smoking Behavior } & $-0,69$ & $-0,85$ & 2,83 & $-0,72$ & $-0,77$ & 0,65 \\
\hline & $(0,72)$ & $(0,52)$ & 0,005 & $(0,70)$ & $(0,64)$ & 0,514 \\
\hline & 848 & 179 & $-0,12$ & 957 & 70 & $-0,07$ \\
\hline \multirow[t]{3}{*}{ Leg Injury } & $-0,46$ & $-0,34$ & $-1,61$ & $-0,44$ & $-0,37$ & $-0,65$ \\
\hline & $(0,89)$ & $(0,94)$ & 0,107 & $(0,90)$ & $(0,94)$ & 0,514 \\
\hline & 847 & 179 & 0,01 & 957 & 69 & $-0,03$ \\
\hline \multirow[t]{3}{*}{ Disease Outbreak } & 0,47 & 0,46 & 0,32 & 0,47 & 0,49 & $-0,41$ \\
\hline & $(0,50)$ & $(0,50)$ & 0,752 & $(0,50)$ & $(0,50)$ & 0,680 \\
\hline & 846 & 179 & $-0,04$ & 955 & 70 & 0,13 \\
\hline \multirow[t]{2}{*}{ Military Convoy } & 0,36 & 0,40 & $-1,00$ & 0,37 & 0,24 & 2,18 \\
\hline & $(0,48)$ & $(0,49)$ & 0,317 & $(0,48)$ & $(0,43)$ & 0,029 \\
\hline
\end{tabular}

Note. Department of Defense data. The table reports the results of t-tests for equality of means for the risk measure indicated in each column by the demographic characteristic in each panel. See text for variable definitions.

Table 6. Comparison of risk measures by select demographic characteristics 


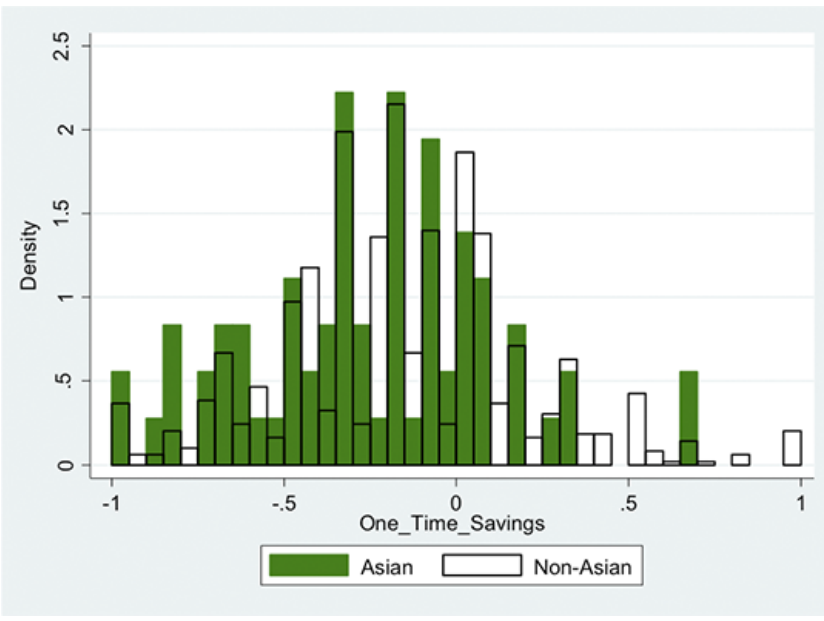

Figure 2

ethnicity and shows significant levels of risk aversion among Asian-American cadets. Figure 2 shows the distribution on the same variable that we examined more closely for female cadets above (One-Time Savings Decision). Again, the distribution of non-Asian responses is right-skewed relative to Asian responses, resulting in a higher average index value. Benjamin et. al (2010) found that Asian-American students at Harvard were both more risk averse and more impatient than white students when unprimed by their racial identity (Benjamin et al, 2010). In our findings, Asian cadets are consistently more risk averse than the non-Asian cadets ( 7 of 11 risk measures). Although our results for Asians are more consistent than for Blacks and Hispanics, they all point in the general direction of more risk-aversion than for comparable Whites; this is similar to previous work with other populations (e.g. Yao, Gutter, and Hanna, 2005).

\section{Conclusions and future research}

By eliciting and then analyzing the risk preferences of a sample of West Point cadets, this paper provides insight on potential patterns of risk aversion among future military leaders. Our experimental design allowed us to examine risk aversion in a controlled environment that trains and graduates students who are now real decision-makers (junior officers) in the U.S. Army. Reassuringly, many of the findings here are corroborated by other studies. First, risk aversion appears to be fairly context-specific. That is, there is no consistent risk aversion response across domains. At the same time, the aggregate relationship (at least pairwise) between self-reported risk aversion and context-specific risk aversion suggests that a core element undergirds responses across domains. The continued search for better metrics of risk aversion are required to develop more appropriate, but still manageable, ways of measuring risk in the field.

Second, females appear to be more risk averse than males, although there were a few areas of exception. Differences in risk aversion across gender has implications in the civilian world, shaping job choice, product choice, parenting choice, and so on. But, with the advent of female participation in combat roles and an increased number of women entering the military, these differences could also have implications for military programs. This is not to say that there is a "right" level of risk aversion. Rather, the systematic differences imply potential differences in decisions/outcomes under similar risky choices. Understanding risk preference decisions, in general, may lead to better job matching for soldiers and better training that more broadly addresses the topics of risk preferences/choices and desired military decisions to reach mission success. It is a topic that needs more study, perhaps by linking objective data on observed performance with risk preference measures.

We find that cadets, as a whole, are risk averse ${ }^{17}$. As Ault (2003) has argued more generally that the structure of the military (i.e., increasing centralization of decision-making) is resulting in a greater level of risk aversion especially within the officer corps. However, the causality seems unclear -does increasing risk aversion in the ranks lead to greater centralization, or does greater centralization lead to greater risk aversion?

Our results might reflect one reason why risk aversion may be increasing within the overall organization: admissions policies favor individual characteristics that correlate with risk aversion. For many good reasons, West Point has increased its recruitment of high academic performers, females, and ethnic minorities, some of which might explain a small part of risk aversion observed in the Army's leadership, although any such claim warrants considerably more study and must be balanced against other gains from increased diversity in the West Point student body and the resulting officer corps.

Of special interest is the linkage between these risk measures and consequential decision-making while in the Army, the existence of similar relationships in other Army commissioning sources (i.e., Reserve Officer Training Corps and Officer Candidate School) and leadership groups (i.e., NonCommissioned Officers), and the influence of leaders' risk preferences on their unit decisions and their subordinates' individual preferences. Decisions, ultimately, are a function of risk perceptions and risk preferences. Holding risk constant, increasing risk aversion in the officer corps will lead to more risk averse decisions. Additionally, structural considerations, such as punishment for incorrect decisions or exposing retirement to higher levels of market risk, will lead to compound effects (higher risk and higher risk aversion) in decisions. The Army Chief of Staff General Mark Milley recently stated that the Army's objective is to create leaders who are willing to tolerate the risks associated with combat operations and other requirements (Tan, 2016), thus these topics should be studied in earnest.

\footnotetext{
${ }^{17}$ Making absolute determinations on risk aversion are difficult. However, many of the measures we use are utilized consistenty in the literature to measure risk aversion. In that regard, we find risk aversion generally, which is not inconsistent with the broader population results using the same elicitation techniques.
} 


\section{References}

Anderson, L. and J. Mellor (2008). "Predicting health behaviors with an experimental measure of risk preference", Journal of Health Economics 27: 1260-1274.

Ault, R. (2003). "Encouraging risk and embracing uncertainty: the need to change the U.S. Army culture", Monograph, School of Advanced Military Studies, United States Army Command and General Staff College, Ft. Leavenworth, KS.

Benjamin, Daniel J., James J. Choi and A. Joshua Strickland (2010). "Social identity and preferences", American Economic Review 100(4): 1913-28.

Berg, J., J. Dickhaut and K. McCabe (2005). "Risk preference instability across institutions: a dilemma", Proceedings of the National Academy of Sciences 102: 4209-4214.

Bonds, D., K. Foley, E. Dugan, M. Hall and P. Exom (2004). "An exploration of patients' trust in physicians in training", Journal of Health Care for the Poor and Underserved 15: 294-306.

Borghans, L., J. Heckman, B. Golstyn and H. Meijers (2009). "Gender differences in risk aversion and ambiguity aversion", Journal of the European Economic Association 7: 649-658.

Charness, G., U. Gneezy and A. Imas (2013). "Experimental methods: eliciting risk preferences", Journal of Economic Behavior and Organization 87: 43-51.

Chuang, Y. and L. Schechter (2015). "Stability of experimental and survey measures of risk, time, and social preferences: A review and some new results", Journal of Development Economics 117: 151-170.

Cleve, B., N. Nikiforakis and R. Slonim (2013). "Is there selection bias in laboratory experiments? The case of social and risk preferences", Experimental Economics 16: $372-382$.

Coble, K., Z. Yang and D. Hudson (2011). "Using experimental economic to evaluate alternative subjective elicitation procedures", Applied Economics 43: 1729-1746.

Cooke, R. and L. Goossens (2004). "Expert judgement elicitation for risk assessments of critical infrastructure", Journal of Risk Research 7: 643-656.

Cubitt, R., C. Starmer and R. Sugden (2001). "Discovered preferences and the experimental evidence of violations of expected utility theory", Journal of Economic Methodology 8: 385-414.
Cullen, M., M. Isaqzadeh, J. Long and C. Sprenger (2014). "Violence and rise preference: experimental evidence from Afghanistan", American Economic Review 104: 123-148.

Dohmen, T., A. Falk, D. Huffman, U. Sunde, J. Schupp and G.G. Wagner (2011). "Individual Risk Attitudes: Measurement, Determinants, and Behavioral Consequences", Journal of the European Economic Association 9(3): 522-550.

Eeckhoudt, L., C. Gollier and H. Schlesinger (1996). "Changes in background risk and risk taking behavior", Econometrica 64: 683-689.

Eckel, C. and P. Grossman (2008). "Men, women, and risk aversion: experimental evidence". Chap. 113 in Handbook of Experimental Economics Results: 10611073.

Einav, L., A. Finkelstein, I. Pascu and M.R. Cullen. "How General Are Risk Preferences? Choices under Uncertainty in Different Domains", American Economic Review 102(6): 2606-2638.

Garyn-Tal, S. and S. Shahrabani (2015). “Type of army service and decision to engage in risky behavior among young people in Israel", Judgement and Decision-Making 10: 342-354.

von Gaudecker, H., A. van Soest and E. Wengström (2011a). "Heterogeneity in risky choice behavior in a broad population", American Economic Review 101: 664-694.

von Gaudecker, H., A. van Soest and E. Wengström (2011b). "Experts in experiments: how selection matters for estimated distributions of risk preferences". Discussion paper series 5575, Institute for the Study of Labor, Bonn, Germany, March.

Halek, M. and J. Eisenhauer (2001). "Demography of risk aversion", Journal of Risk and Insurance 68: 1-24.

Harrison, G. and E. Rütstrom (2008a). "Risk aversion in the laboratory", Risk Aversion in Experiments (Research in Experimental Economics, Volume 12), Edited by J. Cox and G. Harrison. Emerald Group Publishing, 41-196.

Harrison, G. and E. Rütstrom (2008b). "Experimental evidence on the exists of hypothetical bias in value elicitation methods", chap. 81 in Handbook of Experimental Economics Results, 752-767.

Haynes, K., J. Barclay and N. Pidgeon (2008). "Whose reality counts? Factors affecting the perception of volcanic risk", Journal of Volcanology and Geothermal Research 172: 259-272.

Heaton, J. and D. Lucas (2000). "Portfolio choice in the presence of background risk", The Economic Journal 110: 1-26. 
Hoffman, E., K. McCabe and V. Smith (1996). "Social distance and other-regarding behavior in dictator games", American Economic Review 86: 653-660.

Holt, C. and S. Laury (2005). "Risk aversion and incentive effects: new data without order effects", American Economic Review 95: 902-904.

Hudson, D., J. Lusk and K. Coble (2005). "Consistency of risk premium measures", Agricultural Economics 33: 41-49.

Karlson, E., L. Daltroy, M. Liang, H. Eaton and J. Katz (1997). "Gender Differences in Patient Preferences May Underlie Differential Utilization of Elective Surgery”, The American Journal of Medicine 102(6): 524-530.

Kelly, A., W. Killgore, J. Athy and M. Dretsh (2009). "Risk propensity, risk perceptions, and sensation seeking in U.S. Army soldiers: a preliminary study of a risk assessment task battery". USAARL Report No. 2010-02, U.S. Army Aeromedical Research Laboratory.

Keown, C. (1989). "Risk Perceptions of Hongkongese vs. Americans", Risk Analysis 9: 401-405.

Kruger, D. (2004). "Sexual selection in the Male: Female mortality ratio", Evolutionary Psychology 2: 66-85.

Lahav, E., U. Benzion and T. Shavit (2011). "The effect of military service on soldiers' time preferences: evidence from Israel", Judgment and Decision Making 6: 130138.

Lerner, J., R. Gonzalez, D. Small and B. Fischhoff (2003). "Effects of fear and anger on the perceived risks of terrorism: a national field experiment", Psychological Science 14: 144-150.

Lloyd, A. (2003). "Threats to the estimation of benefit: are preference elicitation methods accurate?", Health Economics 12: 393-402.

Lusardi, A. and O. Mitchell (2014). "The Economic Importance of Financial Literacy: Theory and Evidence", Journal of Economic Literature, 52(1): 5-44.

Lusk, J. and K. Coble (2005). "Risk perceptions, risk preference, and acceptance of risky foods", American Journal of Agricultural Economics 87: 393-405.

Lusk, J. and K. Coble (2008). "Risk aversion in the presence of background risk: evidence from an economic experiment", Risk Aversion in Experiments, Edited by J. Cox and G. Harrison. Emerald Group Publishing, 315-340.

McKenna, B., D. Dickenson, H. Orff and S. Drummond (2007). "The effects of one night of sleep deprivation on known-risk and ambiguous risk decisions", Journal of Sleep Research 16: 245-252.
Murphy, J., P. Allen, T. Stevens and D. Weatherhead (2005). "A meta-analysis of hypothetical bias in state preference valuation", Environmental and Resource Economics 30: 313-325.

Pennings, J. and P. Garcia (2001). "Measuring producers' risk preferences: a global risk-attitude construct", American Journal of Agricultural Economics 83: 993-1009.

Reynaud, A. and S. Couture (2012). "Stability of risk preference measures: results from a field experiment of French farmers", Theory of Decision 73: 203-221.

Sapienza, P., L. Zingales and D. Maestripeiri (2009). "Gender differences in financial risk aversion and career choices are affected by testosterone", Proceedings of the National Academy of Sciences 106: 15268-15273.

Simon, C., J. Warner and S. Pleeter (2015). "Discounting, cognition, and financial awareness: new evidence from a change in the military retirement system", Economic Inquiry 53: 318-334.

Tan, M. (2016). "One of the youngest leadership teams in US Army history is rocking the boat", Army Times, October 3.

Tversky, A. and D. Kahneman (1981). "The framing of decisions and the psychology of choice", Science 211, 453-458.

Warner, J. and S. Pleeter (2001). "The personal discount rate: evidence from military downsizing programs", American Economic Review 91: 33-53.

Wilk, J., P. Bliese, P. Kim, J. Thomas, D. McGurk and C. Hoge (2010). "Relationship of combat experiences to alcohol misuse among U.S. soldiers returning from the Iraq war", Drug and Alcohol Dependence, 108: 115121.

Yang, Z., K. Coble and D. Hudson (2009). "The role of individual personality type in subjective risk elicitation outcomes", Journal of Risk Research 12: 209-222.

Yao, R., M.S. Gutter and S.D. Hanna (2005). "The Financial Risk Tolerance of Blacks, Hispanics, and Whites", Financial Counseling and Planning 16(1): 51-62. 